\title{
Mucous Thread Measurement
}

National Cancer Institute

\section{Source}

National Cancer Institute. Mucous Thread Measurement. NCI Thesaurus. Code C74721.

The determination of the number of mucous threads present in a sample. 